\title{
Judicial Review in Acts on Financial Information Access for Taxation Interest
}

\author{
Richard Burton ${ }^{1}$ \\ \{richard.pajak@gmail.com\} \\ ${ }^{1}$ Doctoral Students of Law Science of Jayabaya University, Indonesia
}

\begin{abstract}
This study discusses justice in the implementation of the Law No. 9/2017 on Financial Information Access for Taxation since there is limitation for the tax authority to strengthen the taxation database to meet the optimal tax revenues. The component of tax revenues requires the support from other stakeholders such as financial institutions. The study uses a normative juridical research methodology using primary legal materials, namely the issued laws and other laws relating to tax collection norms and Constitutional Court Decision No. 102/PUU-XV/2017 on the testing of the law on access to financial information; and secondary legal materials such as books, legal journals and other information published in the mass media. This study uses a statutory approach and a case approach. The results of this study are directed to achieve justice and welfare through the regulation of legal norms for the common interest.
\end{abstract}

Keywords: Tax Collection; Financial Information; Law System; Justice and Welfare.

\section{Introduction}

Levy collection is an absolute need for a country although the people do not fond of being charged by taxes. To give more proper understanding about taxes, a French legal expert stated: "Levy collection is a certain part of a property of every citizen set aside to save or to be able to savor the rest of the property normally. To determine the proper levy collection, there must be a consideration over the need of the state or the need of the citizens..."[1]

The above understanding did not emphasize the element of 'forcing' as firmly defined within the tax acts. The phrase 'consideration about the need of the state' mentioned by Montesquieu provided a deep meaning that it was not easy for a state to make an established consideration in arranging the norms of levy collection that could provide justice, without emphasizing the element of forcing.

When the need of the state keeps increasing every year with a real target mentioned in the Act of National Budget (UUAPBN) the fulfillment of the need of revenue from tax sector remains dominating the number of APBN stipulated. Facing such condition, a space for tax potency becomes a particular thought yet it has to remain based on justice, especially tax potency space in financial information access which is constrained by the existence of other Acts providing protection for the funds owners who keep their funds in various financial institution. It could be conducted by the state since it has the right to collect levy from their citizens. The right in legal concept is the right over other people's deed, over the deed that according to law is an obligation of other people.[2]

The need of funds with trillion rupiah increase for the prosperity and the welfare of the people, takes a vast access for the tax authority to obtain financial information for tax interest as the tool to supervise the fulfillment of tax obligation based on self-assessment system.[3] the availability of financial information access provides expectation of the compliance over tax to 
become more optimal, since the database of tax becomes stronger and at the same time narrow down the space to put illegal funds that are possible to be used by the parties who try to disobey tax. Moreover, with the current global economy, and inevitable international cooperation for such automatic financial information exchange with international standard, the need of financial information access is highly needed by the tax authority.

Even though the levy collection is carried out based on self-assessment system, the issue of justice including legal certainty has not fully manifested yet because it is not easy to establish tax legal norm that could be accepted by many parties.[4] To face this issue, an Act of Financial Information Access for Tax Interest No. 9 of 2017 (applied started from May 8, 2017) was issued, and it could be said that it did go very smooth since it would face some 'resistance' by judicial review to Constitutional Court (MK). Decree of MK. No. 102/PUU-XV/2017 (signed on 30-04-2018) denying the entire plea by the pleader, to give meaning how it is not easy to give justice in levy collection. MK decree has provided legal certainty that the norms in the Act of Financial Information Access for Tax Interest, was not against the constitution. Based on such background, the perspective of justice in levy collection context regarding with financial information access becomes interesting to analyze in this paper.

\section{Methods}

This research used normative judicial research method using primary legal material especially acts in the field of tax that has been issued or other acts related to the norm of levy collection. Besides, secondary legal materials in the form of publication about law such as textbooks, legal journals and decision of court related to levy collection issues and other information in the form of article published in mass media were also used. The research was carried out using legislation approach, case approach as well as philosophy approach i.e. about justice in levy collection system.

\section{Result and Discussion}

\subsection{Tax Interest Through the Expansion of Information Access}

Referring to the need of tax increase targeted within the UUAPBN every year, a step to expand the access to obtain financial information for tax authority is needed with an Act, since it is a means to achieve people's prosperity (welvaarstaat principle). ${ }^{1}$ Such step becomes an inevitable part since one of the sources of tax potency is asset or taxpayer property saved in various financial institutions that the tax obligation have not been fulfilled. Such expansion stage is a continuation of tax amnesty policy which has been defined in letter $b$ in the part of consideration of Act No. 9 of 2017.

Tax need for welfare purpose based on the constitution needs a concern from the stakeholders so that financial information access will not be constrained by the confidentiality norms of the owner's institution or financial saving institution. Since the tendency of interpreting funds saving confidentiality in financial institution has been seen as save since it is protected by the Law. Similarly, certain countries have policy to provide safe steps for money depositor in their countries.

\footnotetext{
1 Purnadi Purbacaraka and Soerjono Soekanto, Perundang-Undangan Dan Yurisprudensi, Alumni, Bandung, 1979, p. 19.
} 
Legal issue becomes very serious when the purpose of legal justice was demanded by many parties related to the tax charges over the funds they save in financial institution, the tax have not been paid. One of the purposes of the issuance of Act No. 9 of 2017 provides justice in ley collection system so that the taxpayers could contribute through tax payment to the country's development. Firmly, justice is created since the hidden financial information could be identified (inside or outside the country), so that taxpayers are obliged to pay the tax that should be paid based on the Act of tax.

In the context of tax, the meaning of justice could be said simple. If someone has property (money) and income but s/he has not paid the tax, then over the property mentioned must be charged by tax. On the contrary, if over the property or money obtained and saved in financial institutions have been charged with tax, no more tax should be charged. If Mr. Ali has some money in Bank ABC but over the money, tax has been charged, Mr. Ali does not need to worry if the existence of his money was identified by tax authority. A concern commonly occurs since the money saved has not been reported and the tax has not been paid. The Act of Financial Information Access for Tax Interest No. 9/2017 intends to target such condition. How much properties (money) saved in financial institutions (inside or outside the country), is not a problem. It becomes serious matter if the account owner is afraid because the tax has not been charged over the properties.

Justice in understanding financial information access for tax interest is in line with the justice principle in levy collection. It means that the tax weigh allocation on various group of people should reflect justice with two common criteria used to see if the allocation of tax weight has reflected the aspect of justice. The first criteria is ability to pay, i.e. if some has higher ability to pay is charged by higher tax weight proportion. Second criteria, benefit principle i.e. benefit is considered fair if someone who obtain bigger savor from the public services provided by the government is charged by bigger tax weight proportion.[5]

Taxpayers who save their money in financial institution currently feel safe since the institution on behalf of 'confidentiality' becomes an assurance for them, as regulated in the norm Article 40 and 41 of the Act of Banking No. 10 of 1998. However, if the issue of 'confidentiality' of the institution does not apply especially for tax interest based on the Act No. 9 of 2017, there would be public reaction for judicial review to Constitutional Court. The legal choice to do judicial review is very correct, to assess the judicial side of the implementation of Act. No. 9 of 2017.

In the analysis of the author, there are at least three reasons for the implementation of Act. No. 9 of 2017 to manifest justice for the success in levy collection, they are:

1) World globalization which is inevitable or terminated. Common explanation of Act No 9 of 2017 confirming the international world development to exchange financial information automatically based on international standard. If it was not carried out, then Indonesia would be categorized as the country that takes side to non-transparency (a country which is non-cooperative jurisdiction). Global forum on transparency and exchange of information for tax purpose (Global Forum) with the number of members of 139 countries shows inevitable globalization.

2) The need of justice in levy collection system. The implementation of tax amnesty program through Act No. 11 of 2016 implemented for nine months (since July 2016 to March 2017) and is expected to provide justice in tax paying compliance, incurs a debate over justice. Tax amnesty is seen only provide amnesty for tax evaders and it is seen not fair for obedient taxpayers. Tax amnesty has an impression to provide an expectation that the tax paid would increase revenue.[6] Even the tax amnesty policy is considered by the government as the most proper effort to increase tax revenue and withdraw the 
funds of Indonesian citizens saved in abroad, even though it once was carried out in 1964 and 1984. Therefore, from the justice side, tax amnesty is a form of unfair treatment since there has been a special treatment for taxpayers who are not obedient get the amnesty not to pay the tax and its tax punishments are dismissed.[7]

3) Financial information access resistance for the existence of confidentiality norm in some Acts. At least there are ten norms from five Acts revoked on Article 8 of Act No. 9 of 2017 related to the implementation of financial information access for tax interest. Whereas there are at least two more Acts that should be synchronized so that the tax justice could be carried out, i.e. (I) Act No. 8 of 2010 about Prevention and the Eradication of Money Laundry (UUTPPU), and (ii) Act No 24 o 1999 about foreign exchange traffic and exchange rate system (UULLD). In UUTPPU, the report of financial service is only directed to the center of report and analysis of financial transaction (PPATK) while UULD, the information and data providing are only given to Bank Indonesia.[4]

Those three reasons give a meaning that levy collection is the one that serves justice since it provides a common treatment for everyone who has not paid the tax yet. Such perspective is in line with Sindian who emphasizes state authority in levy collection must be shown for public welfare so that it serves justice.[8] Transparency in gaining financial information access is a legal step to create justice for common obligation in fulfilling taxes based on the legislation. The space of fairness of levy collection is the central point that is indisputable. Act No. 9/2017 is the central point of justice in global context. Because it does not give a common treatment for money owners (either domestic or foreign taxpayers) who save in Indonesian financial institutions. Exchange of information becomes a way to create justice in levy collection system.

\subsection{Tax Justice Test Through Act Testing}

The norm formulation of Article 1 of Act on Financial Information Access for Tax Interest No. 9/2017 stated: "Financial information access for tax interest including access for receiving and obtaining financial information in order to implement the provision of legal regulation in the field of tax and the implementation of international agreement on tax".

The norms above strictly stated that only tax interest addressed in the meaning which obtain financial information access, not other legal interest such as civil code or criminal code. Tax interest is justice interest so that the funds (money) owners who have not paid the tax, to pay the tax based on the Act of Tax. However, the meaning of the above norms by the pleader of testing is understood differently. The test pleader states the warranty, protection and legal certainty could be violated by banking/other financial service institution ruled in Article 28D, 28G, of 1945 Constitution.

According Decree of Constitutional Court No. 102/PUU-XV/2017 that the mistake of understanding the confidentiality then was defined by the government by stating that the confidentiality revealed in the norms of Act outside the tax is only implemented for tax interest. While confidentiality interest outside the tax interest remains applied. In other words, financial institution remains responsible for keeping the confidentiality of financial information from the customers outside tax interest. Legal argument is strengthened by Zainal Arifin Mochtar by quoting legal principle that the Act applied nowadays cancel the Acts applied previously (lex posteriore derogat lex priori).

In such context, the author suggests that when the tax justice becomes the demands of the country and the public welfare interest, the confidentiality in the Act of Banking, Act of stock market, and other Acts limiting the tax interest, should be said as contradictory Acts and does 
not have philosophy foundation in the meaning of levy collection for the state interest (public welfare). The confidentiality of legislation outside the Act of tax should be harmonized and may not resist justice interest in levy collection. Therefore, the harmonization of legal norms is legal politic of norm establishment that must fully support the interest of the right of the state in levy collection.

About the non-applied confidentiality in ten norms of 5 Acts in Article 8 of Act No.9/2017 in relation to the Article 28j paragraph (2) of 1945 Constitution, in the context of justice, its legal argument is explained by the Judge of Constitution Court, the author quotes as follows:

First, ... data and information opening belong to someone or an entity related to the suspicion of being involved in tax evasion would directly be related to an effort to fulfil human rights, in this case the including in the group of the rights of economy, social and culture in which its fulfillment requires the government /state, as confirmed by Article 281 paragraph (4) of 1945 Constitution, saying that in this case through the implementation of development where tax is one of the main sources of the funds.

Second, the exception of data and information confidentiality related to the suspicion of tax evasion is clearly against the principle of fair demand fulfillment based on moral consideration, religious values, security or public order in a democratic society.

Two argument of justice become the keys in interpreting financial information access with confidentiality that becomes the pleader's legal reason. The decree of Constitutional Court provides the test of justice meaning in the interpretation of financial information access that should be able to be obtained by tax authority for the tax interest. Justice in levy collection is justice for the welfare interest as confirmed by the third paragraph of the preamble of 1945 Constitution that should be understood by all.

\section{Conclusion}

The current number of job seekers (prospective workers) in Indonesia is not comparable with the number of companies seeking for employees. A lot of fresh graduates who explore the world of work and look for a job finally find a job which does not match their educational background. Thus, they have to accept the job with work experience from the very bottom level. On the other hand, a lot of companies make strict requirement for the position offered. It is related to the income of companies that are used to pay workers.

It is considered that the government is not serious to overcome the problem of outsourcing. This leads the workers do not have legal certainty. In this case, the Government cannot implement the 3 (three) labor principles as stipulated by the ILO. Thus, when the work contract ends, it will be extended for years, even decades. It can be said that the Government does not reduce contract labor which is basically not in accordance with the 1945 Constitution. As a result, the outsourcing workers follow the "market flexibility" system meaning that they have no other choice to work in a particular company with an outsourcing system.

\section{Acknowledgments}

The author would like to thank and give an appreciate to the Head of Semarang State University for providing a facility to join International Conference in ICILS 2020. 


\section{References}

[1] Montesquieu, The Spirit of Laws: Dasar-dasar Ilmu Hukum dan Ilmu Politik. Bandung: Nusa Media, 2007.

[2] J. Asshiddiqie, Pokok-Pokok Hukum Tata Negara Indonesia. Jakarta: Bhuana Ilmu Populer, 2007.

[3] S. Nurmantu, Pengantar perpajakan. Jakarta: Kelompok Yayasan Obor, 2010.

[4] W. B. Ilyas and R. Burton, Perspektif Keadilan dan Kepastian Dalam Penerapan Hukum Pajak. Jakarta: Mitra Wacana Media, 2018.

[5] Miyasto, "Sistem Perpajakan Nasional Dalam Era Ekonomi Global," Semarang, 1997.

[6] T. D. Anggraini, "Keterpenuhan Prinsip Keadilan Dalam UU Pengampunan Pajak," $J$. Rechts Vinding, vol. 5, no. 2, p. 117, 2016.

[7] N. Sa'adah, "Kebijakan Pengampunan Pajak (Tax Amnesty) Berdasarkan Keadilan Yang Mendukung Iklim Investasi Indonesia," Masal. Huk., vol. 46, no. 2, pp. 182-189, 2018.

[8] S. I. Djajadiningrat, Hukum Padjak Dan Keadilan. Bandung: Fresco, 1965. 